on reclaimed upland areas in Montgomeryshire are described, in which re-seeding appears to have considerably improved the carrying capacity of the land. Practical advice on silage-making and its place in good grassland management is the subject of a further article, silage both being a valuable food and a useful means of controlling the sward and, moreover, not entailing heavy capital outlay or expensive equipment. From a detailed account of severe leather-jacket attack on re-seeded grassland in Yorkshire, there seems at present no really efficient means for controlling this pest on a farm scale, though attention to drainage, close grazing during the late summer when egg-laying takes place, and the maintenance of fertility are evidently factors which may lessen the degree of attack. A feature of this first number are the good photographs which illustrate each of the articles.

Japanese Men of Science in Malaya during the War

Dr. H. Desch writes to state that he wishes to make/t clear that he does not endorse the conclusion and inferences to be drawn from Mr. E. J. H. Coryor's letter on this subject which appeared in Nature of July 13. $\mathrm{He}$ is not prepared to enter into a lengthy correspondence, but directs attention to on e point of fact. The format of Symington's 'Foresters' Manual of Dipterocarps" was in no way determined or influenced by the Japanese; it was already in page proof before the Malayan campaign, and half the page formes survived the effects of blast from demolitions adjacent to the Caxton Press works. Because of this fact, Mr. Lebroy of the Caxton Press reset the remainder of the work and printed the whole for a figure that the Japanese ultimately accepted. Re-setting was done from a galley proof handed to Dr. Dqsch by Mr. Symington's Malay assistant.

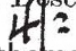

Mathematics at University College, Southampton : Prof. E. T. Davies

DR. E. T. DAviEs, tho has just been appointed to the chair of matb fatics at University College, Southamptom iQ ond the outstanding leaders of research in hodern differential geometry. $\mathrm{He}$ grapurted lat the University College of Wales, Af $y$ t tw $h$, in 1925, and was awarded a research studentship which took him to Rome to study under Levi-Civita. The next two years he spent working under Cartan at the Sorbonne. His researches in Rome and Paris under two great geometers had a decisive influence on his future work. Since 1930 he has been lecturing at King's College, London, and has been developing a fertile and original field of research which may be generally described as resulting from the action and reaction of differential geometry and the calculus of variations. $\mathrm{He}$ has studied problems of deformation of sub-spaces, of 'imbedding', of automorphism, and of the variation of multiple integrals. His later papers give a unified treatment of all geometries having a vector density as element of support, and thus generalize the work of Carton and Finsler. His new appointment, which he takes up at the beginning of 1947 , will give him the opportunity to build up a school of research workers in this interesting and important field.

\section{University of London: Appointments}

THE foll fwing appointments recently made by the Uniy resity of London have been announced: Dr. Zrank Dickens, during 1933-46 researeh
Jirector for the North of England Council of the British Empire Cancer Campaign, to the Philip Hill shair of experimental biochemistry tenable at the Middlesex Hospital Medical School as from March 1, 1946 ; Dr. J. F. Danielli, during 1942-45 research ellow and supervisor in physiology at St. John's Jollege, Cambridge, to the University readership in sell physiology, tenable at the Royal Cancer Hospital as from October 1, 1946 ; Dr. J. L. D'Silva to the University readership in physiology tenable at St. Bartholomew's Hospital Medical College, where he has been lecturer in physiology since March 1944 ; Dr. J. M. Robson, senior lecturer in pharmacology in the University of Edinburgh, to the University readership in pharmacology tenable at Guy's Hospital Medical School as from October 1, 1946. The title of reader in applied entomology in the University of London has been conferred on Dr. A. B. P. Page in respect of the post held by him at the Imperial College of Science and Technology.

\section{University of Glasgow: Appointments}

THE folloy 6 appointments have been made in the Univesity of Glasgow: John E. Parton and Douglas S. Gordon to be lecturers in electrical enging ring, and A. J. O. Cruickshank as an assistant ; John S. Macpherson, W. A. Donaldson and D. D. McKinnon to be assistants in mathematics; and Robin Giles as an assistant in natural philosophy.

\section{University Coلllege, Hull : Appointments}

Untversply College, Hull, has made the following prombtions and appointments in the Faculty of Scienco: Paul G. 'Espinasse to be professor of zoolbgy; R. D'O. Good to be professor of botany; Dr. B. Jones to be G. F. Grant professor of chemistry in succession to Prof. F. G. Tryhorn; Dr. B. T. Cromwell to be reader in botany; Miss M. A. Tazelaar to be lecturer in zoology. The following have been appointed assistant lecturers : J. W. F. Bell (physics), D. P. Brachi (geography), Dr. A. Cunliffe (physics), Miss L. R. Latham (geography), Mrs. H. Neumann (mathematics), E. R. Trueman (zoology), J. Webster (botany). A. Saville has been appointed research biologist in the Department of Oceanography.

\section{Announcements}

THE fo/lwing appointments have recently been made by the Colonial Office: A. B. Briars, to be agrigutural officer, Nyasaland; J. F. Graham, to be sypernumerary entomologist, East African Locust Directorate, Kenya ; A. D. T. Montague, agricultural officer, Gold Coast, to be senior agricultural officer, Gold Coast; R. O. Roberts, geologist, Uganda, to be chemist and petrologist, Uganda.

Mr. J. A. Young has been appointed assistant agricultura adviser to the High Commissioner for the Unit Kingdom in Canada, and will be stationed at Ottawa. He will assist in that capacity Mr. A. N. Dukkham, the agricultural adviser to the High Commissioner, who is also the agricultural attaché at the British Embassy in Washington. Mr. Young was educated at Dungannon Royal School and Queen's University, Belfast, where he obtained the degree of B.Agr., with distinction. After leaving the University he was appointed to the inspectorate of the Ministry of Agriculture for Northern Ireland and latterly has been mainly engaged on technical and agricultural education work. 